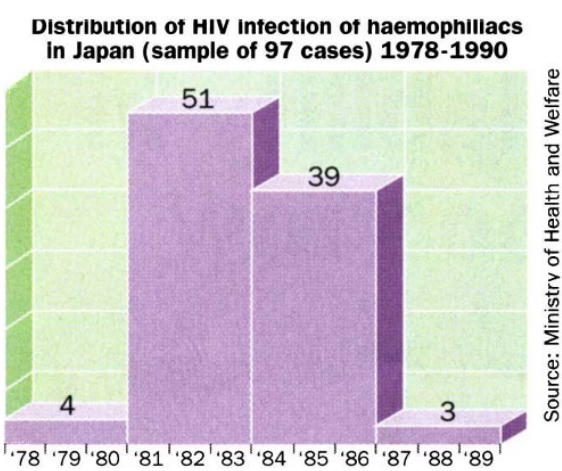

$\checkmark$ the government's share of the original proposal made by the courts would be $¥ 32.4$ billion (about US $\$ 300$ million) if compensation were offered to all 1,800 victims.

Apart from Kan's apology, there have been other indications that a resolution may be in sight. These include a recent announcement by Ryuichi Hashimoto, the prime minister, that a new compromise proposal to be issued by the Tokyo and Osaka courts at the end of this month will include measures to ensure the welfare of victim's families - a demand not dealt with in the previous proposal.

The government's admission of responsibility may also spur investigation into accusations of criminal liability and perjury that have been filed against some former ministry officials by the plaintiffs. Last week, the mother of a victim who died in 1991 filed an accusation of murder with the Tokyo District Prosecutor's Office against Takeshi Abe, who headed an MHW AIDS study group that advised continued use of nonheat-treated blood products in 1983.

The mother claims that her son was infected after receiving transfusions of coagulant from Abe in April and June 1985, well after Abe had learned in late 1984 that 23 out of 48 haemophiliacs receiving the same kind of blood products under his care had been infected with HIV

The new charges follow an earlier accusation of "wilful negligence resulting in death" filed against Abe in 1994 (see Nature 368, $680 ; 1994)$, and a perjury charge filed last month against Atsuaki Gunji, the head of the division within the ministry's pharmaceutical affairs bureau that set up the study group. Noma says that the newly discovered documents may prompt the prosecutors into action over these outstanding accusations.

Gunji, now a professor of public health at Tokyo University's Faculty of Medicine, has been accused of lying to the Tokyo district court in 1993 when he twice testified that ten years earlier he had been unaware that the transmission routes for HIV and the hepatitis-B virus were probably similar (see Nature 369, 388; 1996). The documents recently unearthed at the ministry, some written by Gunji, are said to contradict this testimony. But neither Gunji or Abe will comment publicly on the court cases, on the matter of the files, or on the accusations against them.

Stephen Barker \& David Swinbanks

\title{
Scientists urged to turn their attentions to nuclear waste
}

Washington. The United States government is turning to basic science in an attempt to find new approaches to the massive task of cleaning up its nuclear weapons complexes. The Department of Energy (DoE) is inviting grant applications from scientists at universities and national laboratories for basic research into ways of simplifying the problem; the cost of the clean-up could be as high as $\$ 1,000$ billion. and it could take as long as 75 years.

Under the new programme, $\$ 50$ million will be made available this year in grants of between $\$ 100,000$ and $\$ 300,000$. The total will include $\$ 20$ million for university research groups, and $\$ 20$ million to support work in DoE laboratories. Critics claim that the funding level is far too low, given the scale of the problem; but the budget may grow in subsequent years.

"This is the first pure science programme we have undertaken," says Tom Grumbly, assistant secretary in charge of the DoE's Office of Environmental Management (OEM). Over the next few years, Grumbly predicts, the programme will build up a "strong and dedicated guild" of scientists devoted to the clean-up problem.

The programme, says Grumbly, will give both the US and the international research community the opportunity to participate in "closing [a] circle" which began with the development of the atomic bomb. Scientists outside the United States are, at least in theory, eligible to apply for the grants.

Grants will be available to investigators in chemistry, biology, geophysics and any other branches of science with potential relevance to the clean-up of the sprawling weapons complex. Problems to be dealt with include the characterization of nuclear waste, the in situ treatment of buried waste, the behaviour of plutonium and the implications of treatment on ecosystems.

An invitation for grant proposals published in the Federal Register on 9 February specifies that brief pre-applications need to be received by 28 February and full proposals by 8 May.

The programme is starting in a hurry and a year earlier than the DoE had been planning - because John Myers (Republican, Indiana), chair of the House of Representatives appropriations subcommittee with jurisdiction over the department, forced the inclusion of the money in this year's appropriations bill.

Grumbly has long argued that scientific research should lead the clean-up process. Until now, however, no money has been devoted directly to it. The OEM spends $\$ 80$ million a year with universities, he says, but that money is intended to develop existing clean-up technologies.

The Galvin Commission, which issued a scathing assessment of DoE laboratories last February (see Nature 373, 463; 1995), suggested that an annual $\$ 400$ million of the OEM's $\$ 7$ billion budget be transferred immediately to science and technology, rising to $\$ 800$ million later.

But the department is under constant pressure to produce immediate clean-up results, while keeping as many people as possible employed on the now-redundant nuclear weapons sites; 13,000 people, for example, work at the most heavily contaminated site at Hanford in Washington state.

Galvin also criticized the lack of scientific

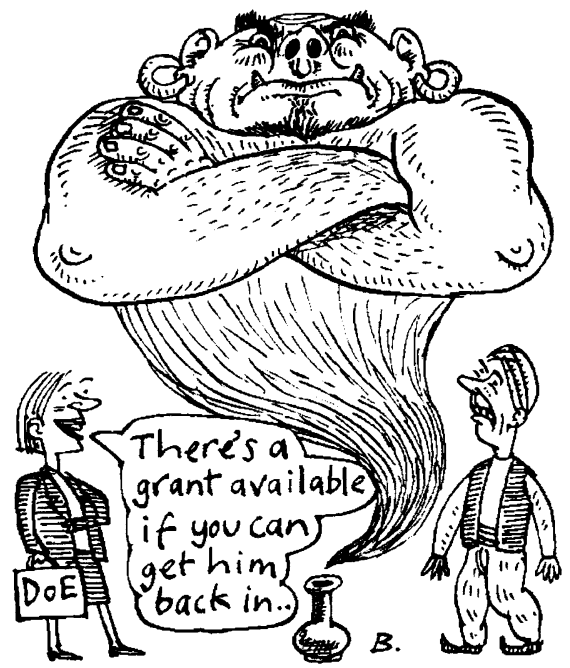

expertise in Grumbly's office. The new programme will therefore be run in partnership with the DoE's Office of Energy Research (OER), which will help to organize the external peer review of grant applications.

Michelle Broido of OER says that grant applications from both university and DoE laboratory applicants will be peer reviewed "subject to the same criteria". But, under US law, the laboratories cannot compete with universities for the same money, and $\$ 20$ million will therefore be set aside for each group.

Grumbly says that the programme will "develop a community of scientists who will bridge the gap" between environmental scientists in the universities, who have traditionally been funded by the Environmental Protection Agency (EPA), and the nuclear scientists and engineers in the weapons complex who have recently turned their attention to the clean-up problem.

$\mathrm{He}$ adds that the science programme might take " $8-10$ years" to produce results applicable to clean-up. The National Academy of Sciences will be asked to evaluate the programme.

Colin Macilwain 